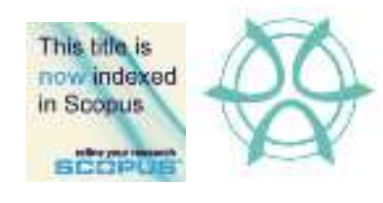

\title{
HOUSING PREFERENCES: AN ANALYSIS OF MALAYSIAN YOUTHS
}

\author{
Suhana Ismail ${ }^{1}$, Azima Abdul Manaf ${ }^{2}$, Mohd Yusof Hussain ${ }^{3}$, Noraliza Basrah ${ }^{4}$, \\ Fatin Umaira Muhamad Azian 5 \\ ${ }^{1,4}$ Faculty of Architecture, Planning and Surveying, \\ UNIVERSITI TEKNOLOGI MARA \\ ${ }^{2,3,5}$ Faculty of Social Sciences and Humanities, \\ UNIVERSITI KEBANGSAAN MALAYSIA
}

\begin{abstract}
Housing preferences among Malaysian youths are an important issue because the housing unit prices nowadays are often unaffordable. Malaysian youths confront various challenges nowadays, including marriage, relocating away from home upon graduation, and finding new work opportunities. Youths have developed into the primary section of the housing market who are constantly faced with housing options and decisions. Besides, youths have different preferences for housing characteristics throughout their particular stage of life, which will significantly impact their future lives. Data was gathered from a survey questionnaire answered by 174 Shah Alam youths aged from 18 to 35. This research focuses on identifying the preferred types of houses chosen by youths, involving features such as location, housing price and type of house to live in. The results also showed that the highest-ranked preferred factors were the financial factors, followed by the neighbourhood, location, and design factors.
\end{abstract}

Keywords: Housing preference, youth

\footnotetext{
${ }^{1}$ Lecturer at Universiti Teknologi MARA. Email: suhanaismail@uitm.edu.my
} 
PLANNING MALAYSIA

Journal of the Malaysia Institute of Planners (2021)

\section{INTRODUCTION}

Vision 2020 envisions a fully developed Malaysian society in all aspects, not only economically but also socially, justly and politically stable. Malaysian should enjoy a best quality of life, social wellbeing and spiritual values.

The younger generation has a hard time purchasing a property. House purchasers are discovering that acquiring their ideal house has become significantly more complicated. Unfortunately, the costs of potential properties tend to be above their budget. Young adults seem unable to buy a decent, adequate, and livable property that does not force them to take out a large bank loan or relocate to a remote and unexciting housing development that requires lengthy daily travels.

$\mathrm{Wu}(2010)$ indicated that because youths are undergoing a tough time of life, such as leaving the family house for employment prospects and marriage, they are likely to have different housing preferences. As a result, youths frequently consider the environmental factors and services available in a particular locality while acquiring a home. According to a study by Gateshead Council on April 2009 survey determined that young people's housing needs and ambitions, the critical need of young people in terms of housing is for additional housing alternatives since many young people feel constrained by their present housing options.

Many researchers have endeavoured to clarify homebuyers' preferences based on demographic and socio-economic characteristics. Based on classic research conducted by Rossi and Weber (1980), housing choices might vary by age, household capacity, income, and present housing situation.

Most studies on housing preferences are generally concerned with demographic and socio-economic factors, such as different age groups and family size (Berko, 2000). According to Al-Momani and Box (2000), the preference factors are lifestyle, values and family patterns. Other factors are education, age, family income and the nature of a buyer's employment organisation (Wang and Li, 2006).

\section{RESEARCH BACKGROUND}

Youths, especially those living in metropolitan regions such as the Klang Valley, are presently facing real challenges in purchasing a home as the cost of housing continues to grow at an alarming rate. Youths can be considered the most active population in terms of migration. According to Hoek J. (2016), young adults represent the cohort or age group between 18 and 35 years old. People in this age range can translate from their parents home to become independent and start to build an individual household of their own. According to Heath (2008), youths frequently take a 'live for today' approach toward financial planning, whereas saving is viewed as an 'adult' behaviour. Youth have the lower-than-average financial knowledge and limited access to financial services. Leaving the family 
Suhana Ismail, Azima Abdul Manaf, Mohd Yusof Hussain, Noraliza Basrah, Fatin Umaira Muhamad Azian Housing Preferences: An Analysis of Malaysian Youth

home frequently results in an increased awareness of one's financial responsibilities.

High housing costs have meant youths prefer to choose rental units rather than purchasing a house. Youth are more likely than other age groups to experience homelessness and rent housing. Additionally, the majority of people acquire their first house in their late 20s or early 30s (Hong, 2011). This situation shows that many youths, in particular, are unlikely to own or purchase a house. For example, a survey conducted by Malaysian government workers Zaimah et al. (2012) on 250 youths under 40 discovered that only $40 \%$ of respondents owned their homes. Another study reported that the housing problem in Malaysia is more related to accessibility issues for the low-income group (Junaidi et al., 2012), including youths. This scenario because of the low supply of low-cost or affordable housing, as well as the low-income level among locals.

According to the Star (2014), fifty (50) percent of Malaysia's population was forty (40) years old or younger. Thus, based on this scenario, half of Malaysia's population is expected to be youths who are disadvantaged in the housing market.

Housing is a basic human need that maintains people's quality of life. Additionally, a house is a safe place that reflects cultural perceptions and occurrences. It is a cultural unit of space that encompasses actions that occur and vary in their significance and use as fundamental rituals (Al-Homoud, 2009). Thus, housing should not have been built or given just for the purpose of providing shelter but also to accommodate people's preferences and other requirements. Considering the housing issues and scenarios, this study aimed to identify youth housing preferences and develop suggestions based on the research findings.

\section{LITERATURE REVIEW}

Housing preferences are distinguished into two related terms, which are housing expectation and housing aspiration. Housing aspiration refers to a future-oriented desire for housing or standards, whereas expectation refers to a realistic evaluation of future housing circumstances (Thanaraju et al., 2019).

The importance of investigating the relationship between housing preferences and personal characteristics is due to the consequent ability to identify variations in housing preferences between different population groups (Shi, 2000). If it is established that different segments of the population have distinct housing preferences, this will have a substantial impact on housing design and research. For example, it is believed that older people like to live in areas near open space but not too close to shopping centres. Thus, a housing designer should consider this when building flats or buildings for senior citizens.

Housing affordability for the young generation has deteriorated to precarious circumstances (Nor Suzylah Sohaimi, 2017). A household's housing 
PLANNING MALAYSIA

Journal of the Malaysia Institute of Planners (2021)

choice or decision can be influenced by a variety of socio-demographic factors (Kömürlü, 2013). To instance, household composition is a critical factor to consider when determining housing choices. The size of households results in varying housing demands, which results in distinct housing preferences. Meanwhile, both single-family homes and suburban locations are favourably associated with family size. Secondly, age is an essential factor to consider when determining the composition of households, since as individuals go through their lives, they may require a variety of living environments. Furthermore, marital status probably has an effect on housing preferences.

\section{Housing Preferences}

Housing preferences can be classified into two broad modelling approaches (Harold W. Elder, 1991). The first one is revealed models based on household observational data and actual housing decisions in the proper market. Meanwhile, stated models are predicated on the premise that observed choices would be mirrored in the effect of preferences, market circumstances, and housing availability (Karsten, Lia. 2007). Social-demographic descriptors do not only influence house preferences, but equally important are buyers' intentions and their financial situations (Lim Poh Im, 2018). When no one choice offers a clear benefit, housing preference indecision may lead to deferral. For a long time, researchers have noted that there is no apparent distinction between preference and choice; thus, they are frequently entwined. Ameera (2019) highlighted that decision is frequently motivated by personal preferences.

Also, researchers have emphasised that because the choice is a mirror of preferences, individuals may deduce their preferences just by witnessing their own choices. According to a recent survey, about $60 \%$ of Lagos residents were renters. Because most of the existing housing was provided by private landlords, most of them had to pay rent that was 50-70 percent of their monthly income (Olugbenga Taiwo, Yusoff, and Aziz 2018).

The majority of research that examine consumer housing choices employ the hedonic pricing framework, which is predicated on the concept of housing characteristics or house purchase considerations (Opoku \& AbdulMuhmin 2010). The relevance of housing variables in housing research is emphasised further by their inclusion in discrete choice models of housing, as well as by the numerous empirical studies examining their relative importance in consumers' housing decisions across a variety of national settings. Numerous studies have indicated that various unique housing characteristics and home purchasing variables impact people's housing choices (Ling, 2016).

These range from intrinsic housing attributes such as cost and size, to extrinsic attributes such as exterior design and exterior space, to the neighbourhood and other locational factors such as pollution (Chin, 2016). There has been considerable discussion concerning the relative relevance of internal and 
Suhana Ismail, Azima Abdul Manaf, Mohd Yusof Hussain, Noraliza Basrah, Fatin Umaira Muhamad Azian Housing Preferences: An Analysis of Malaysian Youth

extrinsic factors in house selection. It finds that residential location decisions are influenced by factors such as neighbourhood and school quality, as well as perceived neighbourhood safety (Salleh, 2015).

Similarly, Levine (1998) discovered that commute time is a significant predictor of the residential location at the regional level. Providing affordable homes near work concentrations can affect low- to moderate-income and singleworker households' residential location preferences. On the contrary, Kauko (2006) discovered that customers prioritise housing functioning and spaciousness above location, whereas Giuliano and Small (1993) claimed that other variables influence location selections more than commute expenses.

\section{Factor Affecting Housing Preferences}

Phan (2012) highlighted the five factors that affect the house purchasing decision, which are the financial status, location, neighbourhood, exterior design and interior design, as shown in Table 1.

Table 1: Factors Affecting Housing Preferences

\begin{tabular}{|l|l|}
\hline Factors & Attributes \\
\hline \multirow{5}{*}{ Location } & Presence of shops nearby \\
\cline { 2 - 2 } & Availability of retail centres nearby \\
\cline { 2 - 2 } & Presence of public infrastructure nearby \\
\cline { 2 - 2 } & Presence of schools nearby \\
\cline { 2 - 2 } & Distance travelled to work \\
\hline \multirow{5}{*}{ Financial status } & Safety neighbourhood \\
\cline { 2 - 2 } & Level of pollution \\
\cline { 2 - 2 } & Presence of guarded and gated security \\
\cline { 2 - 2 } & Green environment \\
\cline { 2 - 2 } & Cleanliness of surroundings \\
\hline Interior design and space & Housing price \\
\cline { 2 - 2 } & Mortgage loan \\
\cline { 2 - 2 } & Payment terms \\
\cline { 2 - 2 } & Income level \\
\hline \multirow{5}{*}{ Exterior design } & Size of the building \\
\cline { 2 - 2 } & Number of floors \\
\cline { 2 - 2 } & Building layout design \\
\cline { 2 - 2 } & Number of bedrooms and bathrooms \\
\cline { 2 - 2 } & Type and quality of finishing \\
\hline & Building orientation \\
\cline { 2 - 2 } & Size of garden \\
\hline
\end{tabular}

These factors and attributes were adopted in order to conduct the questionnaire survey in this study. 


\section{RESEARCH METHOD}

\section{Scope of research}

This study focuses on the parameters of the preferences of Malaysian youths, covering the aspects of financial status, location, neighbourhood and design. The housing preferences of the youth generation of different socio-economic backgrounds, such as age, employment and income, were analysed. Youth is best viewed as a transitional stage between childhood dependency and adult independence. Youth is a more flexible category than other set age groupings. However, age is the most straightforward way to describe this group, particularly in terms of education and work, because the term 'youth' frequently refers to someone between the ages of leaving compulsory education and obtaining their first job (Nations, 2008).

\section{Case Study}

The target respondents were youths staying in Shah Alam, Selangor, and aged between 18 and 35. This research aims to determine the housing preference factors for youths who stay in Shah Alam, which is the capital city of Selangor.

\section{Questionnaire survey and sampling of respondents}

The questionnaire survey was carried out to identify the housing preferences of respondents in the study area. The questions in the questionnaire covered the following aspects:

a) Socio-economic background (e.g., gender, income, education, employment and homeownership).

b) Housing preferences (e.g., location, financial status, neighbourhood and design).

The information was collected by randomly distributing questionnaires to youths in Shah Alam and 174 respondents participated. The respondents were chosen using a simple random sampling technique. The probability that a population sample would be selected was the same for the different housing areas in Seksyen 7, Shah Alam.

The samples covered both male and female residents who had various socio-economic backgrounds and were within the 18 to 35 age group.

Table 2: Background of Respondents

\begin{tabular}{|l|c|}
\hline Variables & Percentage (\%) \\
\hline Gender & $44 \%$ \\
Male & $56 \%$ \\
Female & $5 \%$ \\
\hline
\end{tabular}


Suhana Ismail, Azima Abdul Manaf, Mohd Yusof Hussain, Noraliza Basrah, Fatin Umaira Muhamad Azian Housing Preferences: An Analysis of Malaysian Youth

\begin{tabular}{|c|c|}
\hline $\begin{array}{l}\text { Age } \\
18-21 \text { years old } \\
22-24 \text { years old } \\
25-28 \text { years old } \\
29-31 \text { years old } \\
32-35 \text { years old }\end{array}$ & $\begin{array}{c}7 \% \\
31 \% \\
39 \% \\
10 \% \\
13 \%\end{array}$ \\
\hline $\begin{array}{l}\text { Race } \\
\text { Malays } \\
\text { Chinese } \\
\text { Indian }\end{array}$ & $\begin{array}{l}64 \% \\
17 \% \\
19 \%\end{array}$ \\
\hline $\begin{array}{l}\text { Marital Status } \\
\text { Single } \\
\text { Married } \\
\text { Divorced/Widowed }\end{array}$ & $\begin{array}{c}59 \% \\
38 \% \\
3 \%\end{array}$ \\
\hline $\begin{array}{l}\text { Number of Children } \\
\text { No Child } \\
\text { One Child } \\
\text { Two Children } \\
\text { Three Children and above }\end{array}$ & $\begin{array}{c}67 \% \\
14 \% \\
9 \% \\
10 \%\end{array}$ \\
\hline $\begin{array}{l}\text { Household Income } \\
\text { RM999 and below } \\
\text { RM1000-RM2999 } \\
\text { RM3000-RM7999 } \\
\text { RM8000 and above }\end{array}$ & $\begin{array}{c}48 \% \\
37 \% \\
9 \% \\
6 \%\end{array}$ \\
\hline $\begin{array}{l}\text { Current Homeownership } \\
\text { Owner } \\
\text { Renting } \\
\text { Family home/shared }\end{array}$ & $\begin{array}{l}11 \% \\
63 \% \\
26 \%\end{array}$ \\
\hline $\begin{array}{l}\text { Length of Stay } \\
1-5 \text { years } \\
6-10 \text { years } \\
11-15 \text { years } \\
16-20 \text { years } \\
>20 \text { years }\end{array}$ & $\begin{array}{c}48 \% \\
32 \% \\
10 \% \\
7 \% \\
3 \%\end{array}$ \\
\hline $\begin{array}{l}\text { Employment } \\
\text { Self-employed } \\
\text { Unemployed } \\
\text { Employed } \\
\text { Housewife/Unpaid work } \\
\text { Student }\end{array}$ & $\begin{array}{c}27 \% \\
6 \% \\
41 \% \\
6 \% \\
20 \%\end{array}$ \\
\hline
\end{tabular}




\begin{tabular}{|l|c|}
\hline Education background & \\
SPM and below & $7 \%$ \\
STPM/Certificate & $6 \%$ \\
Diploma & $31 \%$ \\
Degree & $44 \%$ \\
Master's & $8 \%$ \\
Phd & $4 \%$ \\
\hline
\end{tabular}

Table 2 shows that about $50 \%$ of the respondents were aged between 22 and 28. The majority of the respondents also represented lower-income groups, with forty-eight (48\%) per cent earning below RM999 and thirty-seven (37\%) per cent earning between RM1000 and RM2999. The demographic details also show that only eleven (11\%) per cent of them owned a home, while sixtythree $(63 \%)$ per cent were renting houses and the rest stayed with family members.

\section{METHOD OF ANALYSIS}

The data were analysed using the frequency and cross-tabulation tests provided in the Statistical Package for Social Science (SPSS) software. The analysis's objective was to identify the housing preferences of Malaysian youths living in the study area. The data were analysed to investigate the relationship between the housing choices of the research area's youthful generation and their income level and present housing situation.

\section{THE RESULTS AND FINDINGS}

Table 3: Housing Preferences among Malaysian Youths

\begin{tabular}{|l|c|}
\hline Variables & Percentage (\%) \\
\hline Housing Location & $72.6 \%$ \\
Urban & $14.23 \%$ \\
Suburban & $13.17 \%$ \\
\hline Housing Type & \\
Landed & $60.92 \%$ \\
High-Rise Building & $39.08 \%$ \\
\hline Preferred House to Live & \\
Terrace & $21.78 \%$ \\
Semi-Detached & $10.31 \%$ \\
Bungalow & $17.20 \%$ \\
Apartment & $17.20 \%$ \\
Flat & $4.84 \%$ \\
Condominium & $17.20 \%$ \\
Others & $11.47 \%$ \\
\hline
\end{tabular}


Suhana Ismail, Azima Abdul Manaf, Mohd Yusof Hussain, Noraliza Basrah, Fatin Umaira Muhamad Azian Housing Preferences: An Analysis of Malaysian Youth

\begin{tabular}{|l|c|}
\hline Housing Price & \\
RM42,000-RM100,000 & $38.82 \%$ \\
RM100,000-RM200,000 & $34.94 \%$ \\
RM200,001-RM250,000 & $19.99 \%$ \\
RM250,001-RM500,000 & $4.97 \%$ \\
RM500,001-RM1,000,000 & $1.28 \%$ \\
\hline
\end{tabular}

Table 3 shows the housing preferences of the respondents. In terms of the housing location, the majority of respondents, about seventy-six $(72.6 \%)$ per cent, preferred housing in urban areas. Landed properties were preferred by about sixty $(60.9 \%)$ per cent of the respondents. The houses the respondents preferred to live in were terraced houses, represented by about twenty-one $(21.78 \%)$ per cent, followed by bungalows, apartments and condominiums, each being preferred by about seventeen (17.20\%) per cent of the respondents. Results also indicated that a massive majority of the respondents preferred housing prices below RM200,000, with the preference for the range of RM42,000 to RM100,000 being the choice of about thirty-eight $(38.82 \%)$ per cent, and the range from RM100,000 to RM200,000 being the choice of about thirty-four (34.94\%).

Table 4: Factors Affecting Housing Preferences

\begin{tabular}{|c|c|c|c|c|}
\hline Factors & ITEM & MEAN & $\begin{array}{c}\text { TOTAL } \\
\text { MEAN SCORE }\end{array}$ & RANK \\
\hline \multirow{4}{*}{$\begin{array}{l}\text { Financial } \\
\text { factor }\end{array}$} & Payment terms & 3.6494 & \multirow[t]{4}{*}{3.5830} & \multirow[t]{4}{*}{1} \\
\hline & Income level & 3.6494 & & \\
\hline & Housing price & 3.5862 & & \\
\hline & Mortgage loan & 3.4770 & & \\
\hline \multirow[t]{5}{*}{$\begin{array}{l}\text { Neighbourhood } \\
\text { factor }\end{array}$} & $\begin{array}{l}\text { Cleanliness of } \\
\text { surroundings }\end{array}$ & 3.6667 & \multirow[t]{5}{*}{3.5460} & \multirow[t]{5}{*}{2} \\
\hline & $\begin{array}{l}\text { Presence of guarded } \\
\text { and gated security }\end{array}$ & 3.5575 & & \\
\hline & Green environment & 3.5345 & & \\
\hline & $\begin{array}{l}\text { Safety } \\
\text { neighbourhood }\end{array}$ & 3.4943 & & \\
\hline & Level of pollution & 3.4770 & & \\
\hline \multirow[t]{5}{*}{ Location factor } & $\begin{array}{l}\text { Availability of retail } \\
\text { centres nearby }\end{array}$ & 3.6092 & \multirow[t]{5}{*}{3.5195} & \multirow[t]{5}{*}{3} \\
\hline & $\begin{array}{l}\text { Presence of public } \\
\text { infrastructure nearby }\end{array}$ & 3.5345 & & \\
\hline & $\begin{array}{l}\text { Distance travelled to } \\
\text { work }\end{array}$ & 3.5115 & & \\
\hline & $\begin{array}{l}\text { Presence of shops } \\
\text { nearby }\end{array}$ & 3.5057 & & \\
\hline & $\begin{array}{l}\text { Presence of schools } \\
\text { nearby }\end{array}$ & 3.4368 & & \\
\hline
\end{tabular}


PLANNING MALAYSIA

Journal of the Malaysia Institute of Planners (2021)

\begin{tabular}{|l|l|c|c|c|}
\hline \multirow{5}{*}{$\begin{array}{l}\text { Interior design } \\
\text { and space }\end{array}$} & $\begin{array}{l}\text { Number of bedrooms } \\
\text { and bathrooms }\end{array}$ & 3.5517 & \multirow{2}{*}{3.3961} & \multirow{2}{*}{4} \\
\cline { 2 - 3 } & Size of the building & 3.4943 & & \\
\cline { 2 - 3 } & $\begin{array}{l}\text { Building layout } \\
\text { design }\end{array}$ & 3.4253 & & \\
\cline { 2 - 3 } & $\begin{array}{l}\text { Type and quality of } \\
\text { finishing }\end{array}$ & 3.3736 & & \\
\cline { 2 - 3 } & Number of floors & 3.1954 & & \\
\hline \multirow{2}{*}{ Exterior design } & Size of garden & 3.4425 & \multirow{2}{*}{3.3231} & 5 \\
\cline { 2 - 3 } & Building orientation & 3.1839 & & \\
\hline
\end{tabular}

According to Table 4, the factor that most affected housing preferences, as ranked by the respondents, was the financial factor, with an average mean of 3.5830 . The results were followed by the neighbourhood factor (3.5460), location factor (3.5195) and interior design factor (3.3961). The factor that least affected housing preferences was the exterior design factor, with an average mean of 3.3231

\section{CONCLUSIONS AND RECOMMENDATION}

In conclusion, this study has found that most of the youth who participated as respondents were low-income earners and were renting housing units because they could not afford to own homes. Their preferences show their favour for landed properties, preferably the terraced house type, as well as their need for houses which could be priced below RM200,000 and located within urban areas. The results also highlight that the factor that most affected the youths' housing preferences was the financial factor. The ongoing rise in housing prices was seen as a concern by respondents. Indeed, the majority of property prices might be far greater than the median. Malaysia's housing property is usually viewed as expensive by Malaysian youths due to the disproportionate increase in housing prices relative to income. Corresponding efforts should be made to increase household income, which may be a more sustainable method to close the gap between housing prices and the income of Malaysian youths. As a result, government housing agencies should carry out studies to understand Malaysian youths' housing preferences to strategies for future housing development. It is recommended to focus on the actual demand for housing in order to ensure a steady supply of affordable housing which caters to the needs of the lower- and middle-income population segments. This strategy would ideally prevent a homeless generation from emerging and prevent our youths from drowning in debt, which would result in many social problems. 
Suhana Ismail, Azima Abdul Manaf, Mohd Yusof Hussain, Noraliza Basrah, Fatin Umaira Muhamad Azian

Housing Preferences: An Analysis of Malaysian Youth

\section{REFERENCES}

Al-Homoud, Majd. 2009. "Privacy Control as a Function of Personal Space in SingleFamily Homes in Jordan." Journal of Design and the Built Environment 5 (1): 31 48.

Al-Momani, Ayman H \& P O Box. 2000. "Structuring Information on Residential Building: A Model of Preference," 179-90.

Berko, Lale. 2000. "Residential-Location Preferences According to Demographic Characteristics in Istanbul" 48.

Chin, Kok San (2016) Attributes Influencing Home Buyers' Purchase Decision: A Study of Residential Property in Setia Alam. Master dissertation/thesis, UTAR.

D.Wang \& S.-m.Li. 2006 "Socio-Economic Differentials and Stated Housing Preferences in Guangzhou, China”. Habitat International 30 (2006) 305-326.

Giuliano, G., \& Small, K. A. (1993). Is the journey to work explained by urbanstructure? Urban Studies, 30(9), 1485-1500.

Harold W.Elder. 1991. "Tenure Choice, Housing Demand and Residential Location."

Journal of Real Estate Research, American Real Estate Society.

Heath, Sue. 2008. "Housing Choices and Issues for Youth in the UK." Joseph Rowntree Foundation, York, no. November: 1-41.

Hoek J, Thrul J, Ling P. Qualitative analysis ofyoung adult ENDS users'expectations and experiences.BMJOpen2017;7:e014990.doi:10.1136/bmjopen-2016-014990

Hong, Teck. 2011. "Munich Personal RePEc Archive Home Owning Motivation in Malaysia," no. 34906.

Junaidi AB, Rosmadi F, Amer SG (2012) Penilaian awal impak perlaksanaan Dasar Perumahan Negara terhadap sektor perumahan di Kuala Lumpur. GeografiaMalaysian Journal of Society and Space8(6), 90-108.

Karsten, Lia. 2007. "Housing as a Way of Life: Towards an Understanding of MiddleClass Families' Preference for an Urban Residential Location." Housing Studies 22 (1): 83-98. https://doi.org/10.1080/02673030601024630.

Kauko, T. (2006). Expressions of housing consumer preferences: proposition fora research agenda. Housing, Theory and Society, 23(2), 92-108.

Levine, J. (1998). Rethinking accessibility and jobs-housing balance. Journal of theAmerican Planning Association, 64(2), 133-149.

Ling, Oliver, Hoon Leh, Nurul Amanina Mansor, Siti Nur Afiqah, and Mohamed Musthafa. 2016. "The Housing Preference of Youth in Malaysian Urban Areas: A Case Study Subang Jaya, Selangor.” http://journalarticle.ukm.my/10325/1/6x.fullgeo-mei16-oliver-edam.pdf.

NA Salleh, S Abd Zoher, SA Mahayuddin, Y Abdul, 2015. "Influencing Factors of Property Buyer in Hillside Residential Development." Procedia-Social and Behavioral Sciences 170: 586-95.

Nations, The United. 2008. "Definition of Youth," 2007-9.

Nor Suzylah Sohaimi, Alias Abdullah, Shuid S, Azila Ahmad Sarkawi (2017). Young Professionals Housing Affordability Through Housing Preferences in Kuala Lumpur And A Review on The Means-End Chain Model Vol 15: Planning Malaysia Journal: Volume 15, Issue 1, 2017. 
Olugbenga Taiwo, David, 2018. "Housing Preferences and Choice in Emerging Cities of Developing Countries." Journal of Advanced Research in Applied Sciences and Engineering Technology Journal Homepage 10: 48-58.

Opoku, Robert A., and Alhassan G. Abdul-Muhmin. 2010. "Housing Preferences and Attribute Importance among Low-Income Consumers in Saudi Arabia." Habitat International 34 (2): 219-27. https://doi.org/10.1016/j.habitatint.2009.09.006.

P Thanaraju, PAM Khan, NH Juhari, S Sivanathan, NM Khair 2019. "Factors Affecting the Housing Preferences of Homebuyers in Kuala Lumpur." Planning Malaysia 17 (1): 138-48. https://doi.org/10.21837/pmjournal.v17.i9.593.

PAM Khan, A Azmi, NH Juhari, N Khair, SZ Daud 2017. "Housing Preference for First Time Home Buyer in Malaysia." International Journal of Real Estate Studies. Vol. 11. Number 2, 2017.

Phan Than Si. 2012. "Key Factors Affecting House Purchase Decision of Customers in Vietnam" 2012 (8): 1-30.

Poh Im, Lim \& Yun Fah, Chang, Preference of residential typologies for urban Malaysians, Planning Malaysia Journal, Volume 16 Issue 3 (2018).

R Kömürlü, AP Gürgün, D Arditi 2013. "Drivers of Residential Developers' Marketing Strategies Based on Buyer Preferences: Konut Üreticilerinin Pazarlama Stratejilerini Yönlendiren Konut Alicisi Tercihleri." Metu Journal of the Faculty of Architecture 30 (2): 1-16. https://doi.org/10.4305/METU.JFA.2013.2.1.

Rossi PH \& Weber E (1980) The social benefits of homeownership: Empirical evidence from national survey. Housing Policy Debates.

Shi, Lin. 2000. "Housing Preferences of Residents in Stellenbosch, Master In Consumer Science (Housing)."

Star, The. n.d. "Minister: Study on 'Youth City' to Begin next Year | The Star Online." Accessed November 11, 2019.

Wu, Xiaogang. 2010. "Central Policy Unit the Government of the Hong Kong Special Administrative Region Hong Kong" S Post-80S Generation: Profiles and Predicaments the Hong Kong University of Science \& Technology May 2010," no. May.

Zaimah, R, Sarmila Ms, Azima Am, Suhana Saad, Mohd Yusof Hussain, and N Lyndon. 2012. The Youth Well-Being: A Case Study of Malaysian Public Sector Employees" 6 (6): 150-56.

Received: $12^{\text {th }}$ July 2021 . Accepted: $17^{\text {th }}$ Sept 2021 